\title{
Mottakerinstansen i skoleskriving - En studie av skriveoppgaver fra Normprosjektet
}

\author{
Anne Holten Kvistad ${ }^{\star}$ og Hildegunn Otnes \\ NTNU, Norges teknisk- naturvitenskaplige universitet
}

\begin{abstract}
Sammendrag
I denne artikkelen tematiserer vi mottakerinstansen i skoleskriving, og hvordan denne realiseres i oppgaveformuleringer designet av lærere. Studien tar utgangspunkt i et oppgavemateriale fra Normprosjektet, hentet fra 3. - 7. trinn. I analysene kartlegger vi hvor tydelig mottakerinstansen kommer til uttrykk i oppgavene. Videre presenterer vi ulike kategorier mottakere og gir eksempler på disse. Blant annet ser vi på hvordan læreren er posisjonert som mottaker i skriveoppgavene, og drøfter den doble kommunikasjonssituasjonen som ligger i skolekonteksten. En av målsettingene er å studere oppgaver som er designet av lærere innenfor visse rammer i et forskningsprosjekt, og bruke funnene som utgangspunkt for mer generelle perspektiver. Vi ønsker med dette å igangsette en diskusjon i skriveforskningsmiljøet rundt forståelsen av begrepet autentisk skoleskriving og om hvem som skal være mottakere for elevers skriftlige tekster.
\end{abstract}

\section{Nøkkelord: Skriveundervisning; skriveoppgave; oppgavedesign; autentisitet; mottaker}

\begin{abstract}
The recipient in school writing - A study of assignments in "Normprosjektet".

In this article, we thematise the recipient in school writing, and how this is realised in the formulation of assignments by teachers. The study is based on assignment material for grades 3 to 7 in the project entitled Developing national standards for the assessment of writing - a tool for teaching and learning (Normprosjektet). In the analyses we map how clearly the recipient is expressed in the assignments. We also present different categories of recipients and give examples of them. Among other things, we look at how the teacher is situated as the recipient in the writing assignments, and discuss the double communication situation that lies in the school context. One of the objectives is to study assignments that are designed by teachers within certain parameters in a research project and use the findings as a basis for more general perspectives. In doing so, we want to initiate a discussion within the writing research community on the understanding of the concept of authentic writing in school and on who should be the recipient of the pupils' written texts.
\end{abstract}

Keywords: Writing instruction; writing assignment; assignment design; authenticity; recipient; audience

Responsible editor: Atle Skaftun

Recieved: March, 2019; Accepted: August, 2019; Published: November, 2019

^Korrespondanse: Anne Holten Kvistad, epost: anne.h.kvistad@ntnu.no

(C) 2019 A. H. Kvistad og H. Otnes. This is an Open Access article distributed under the terms of the Creative Commons Attribution 4.0 International License (https://creativecommons.org/licenses/by-nc/4.0/), allowing third parties to copy and redistribute the material in any medium or format and to remix, transform, and build upon the material for any purpose, even commercially, provided the original work is properly cited and states its license.

Citation: A. H. Kvistad og H. Otnes. "Mottakerinstansen i skoleskriving - En studie av skriveoppgaver fra Normprosjektet" Nordic Fournal of Literacy Research, Vol. 5(2), 2019, pp. 100-119. http://dx.doi.org/10.23865/njlr.v5.1644 
The teacher should be at some pains to provide an audience or a reader. Sometimes the audience will be real, sometimes it will be imaginary, but it should never be entirely lacking

(Scott, 1903, s. 325).

Sitatet over er fra tidlig i forrige århundre, og er hentet fra engelskprofessor Fred Scotts kapittel «Philosophy of the Assignment». Scott mente at en lærer aldri burde gi en skriveoppgave til elever uten å spesifisere en mottaker. Han begrunnet dette med at "the consciousness of waiting auditors is the most powerful of all stimuli to expression» (Scott, 1903, s. 325). Selv om de er over hundre år gamle, er Scotts ideer relevante for dagens skriveundervisning - med en vektlegging av et funksjonelt språksyn og de kommunikative sidene ved skriving. I læreplanen for norsk skole (Utdanningsdirektoratet, 2013) blir det framhevet i flere fag at elevene skal kunne tilpasse skriftlige tekster til mottakere. Det har imidlertid vært relativt lite forskning på mottakerinstansen i skolens skriveoppgaver. Det er interessant at så få har stilt spørsmål om hvem norske elever skriver til. I vår studie ser vi nærmere på dette med utgangspunkt $i$ et materiale fra Normprosjektet, et landsomfattende forskningsprosjekt om skriving og vurdering (Berge et al., 2017; Evensen et al., 2016; Solheim \& Matre, 2014) ${ }^{1}$, der elever på 3.-7. trinn har skrevet tekster i mange fag som svar på oppgaver laget av lærerne deres. Lærerne hadde fått noen rammer for oppgavedesign, blant annet at oppgavene burde ha et tydelig formål og en eksplisitt mottaker. Hovedproblemstillingen vår er følgende: I hvilken grad - og på hvilke måter - er mottakerinstansen innlemmet $i$ skriveoppgavene lererne designer for sine elever? I våre analyser og diskusjoner vil vi forsøker vi å svare på problemstillingen gjennom å kartlegge om oppgavene sier noe om hvem som er mottakere, og om disse i tilfelle er kjente eller ukjente, fiktive eller virkelige. Vi ser også på læreren som mottaker for elevenes skriving. Selv om oppgavematerialet er hentet fra et avgrenset prosjekt, er hensikten med denne artikkelen også å tematisere mottakerinstansen i skoleskriving mer generelt.

\section{Tidligere faglitteratur og forskning om mottakerinstansen}

Mottakerinstansen er tematisert både i generell faglitteratur om skriving og i skriveforskningen. Problemstillinger rundt mottakerinstansen er blitt diskutert av blant andre Ruth (1982) og Ruth \& Murphy (1988). I Ruths gjennomgang av forskningslitteratur finner han at et av de sentrale prinsippene for oppgavedesign lenge har vært å etablere «a full rhetorical context» (1982, s. 78), altså å spesifisere en relevant skriverrolle, et formål og en mottaker for skrivinga.

Black (1989) viser til forskning som foreslår at mottakerbevissthet er et kjennetegn på gode skrivere og en nøkkelfaktor for å forklare forskjeller i skriveferdighet (1989,

\footnotetext{
${ }^{1}$ Normprosjektets fulle navn er «Developing national standards for the assessment of writing. $A$ tool for teaching and learning», og ble finansiert av NFR og Høgskolen i Sør-Trøndelag i perioden 2012-2016. I prosjektet samarbeidet forskere fra flere institusjoner, og prosjektet ble ledet av Synnøve Matre og Randi Solheim. Se ellers www.norm.skrivesenteret.no.
} 


\section{A. H. Kvistad og H. Otnes}

s. 231). Ifølge blant andre Flower (1979, s. 36) er det en krevende kognitiv operasjon å ta andres perspektiv når en skriver, særlig for yngre barn. I norsk sammenheng har Rutt Trøite Lorentzen (2009) tatt et oppgjør med oppfatninga om at små barn har dårlig utviklet mottakerbevissthet. Lorentzen viste i egne studier at det ikke er mottakerbevissthet barna mangler, men muligheten til å skrive til reelle mottakere (2009, s. 117). Et annet relevant navn i denne sammenhengen er Anders Mehlum (1994), som har vært en forkjemper for at elever må få det han kaller mottakerhjelp. Han skriver at barn har mottakerbevissthet, men at lærere må hjelpe dem til å videreutvikle den. Han bruker begrepet fjernkontakt-kompetanse om det elevene skal utvikle. Barn skal sosialiseres inn i den store offentligheten, der det ofte er vanskelig å forestille seg hvem som skal lese tekstene. Det er derfor viktig at lærere i løpet av grunnskoleårene synliggjør «stadig flere nære og fjerne og enda fjernere mottakere» for elevene (1994, s. 139).

Mottakerperspektivet har blitt tematisert i store forskningprosjekt om skriving, både i utlandet og i Norge. Fra 80-tallet kan vi for eksempel nevne en studie knyttet til det internasjonale IEA-prosjektet (International Association for the Evaluation of Educational Achievement) (Gorman et al, 1988), som omfattet en flernasjonal skrivetest. Det ble konstruert skriveoppgaver med ulike formål til kjente og ukjente mottakere - som elever fra 14 deltakerland skulle skrive til (Vähäpassi, 1988). Det funksjonelle synet på skriving, og derunder mottakerperspektivet, var også sentralt i rammeverkene for amerikanske NAEPs skriveprøver (National Assessment of educational progress), de norske skriveprøvene (Skar \& Aasen, 2018) - og altså Normprosjektet. Det som skiller Normprosjektet fra de overnevnte prosjektene, er at det er prosjektlærerne selv som har designet oppgavene.

Normprosjektet har rettet oppmerksomheten mot design av skriveoppgaver, både i skolering av prosjektlærerne og i analyser i etterkant. En viktig erfaring ble en erkjennelse av hvor avgjørende oppgaveformuleringene var for skriveprosessene - og for prosjektet i det hele. Oppgaveanalysene har hatt ulike perspektiv. Blant annet har man studert hvilke skrivehandlinger som prioriteres i de respektive skolefagene (Dagsland, 2015, 2018; Jørgensen, 2015; Lykknes, 2015). Andre har vært interesserte i hvordan oppgavene introduseres overfor elevene (Bakke, 2018; Bakke \& Skovholt, 2015) og hvordan elevtekstene svarer på oppdragene (Dagsland, 2015, 2018; Kvistad \& Smemo, 2015). Det har også vært gjennomført analyser av de kommunikasjonssituasjonene oppgavene har invitert elevene inn i (Otnes, 2013, 2014, 2015). Flere av disse studiene peker fram mot at det er behov for å undersøke mottakerinstansen nærmere.

Det fins også nordiske studier der mottakerinstansen har vært sentral. Anna-Malin Karlssons (1997) studerte ungdommers leserbrev, der halvparten var skrevet som svar på et leserbrev i et ungdomsblad og den andre halvparten som svar på en skoleoppgave. Tekstene skrevet i den første «semiosfæren» framsto mer velskrevet og innenfor leserbrevsjangeren enn skoletekstene -selv om elevene hadde fått undervisning $\mathrm{i}$ sjangeren. Karlsson forklarer dette med mangel på en autentisk mottakerinstans i tekstene skrevet på skolen. Tuva Bjørkvold (2013, 2018) har fulgt skriveprosessen til 
en gruppe sjuendeklassinger som deltok i forskningskonkurransen «Nysgjerrigper». Innføring av ulike mottakere i løpet av skriveprosessen - elever på skolen, informanter i forskningsstudien deres og juryen i forskningskonkurransen - så ut til å påvirke elevenes utvikling av teksten. Anne Håland (2013) poengterer i sin studie at valg av mottaker må være nøye gjennomtenkt. Ønsker man at elevene skal bruke fagspråk når de skriver, må elevene få forestille seg mottakere det er naturlig å bruke et fagspråk til. Faren ved å velge en mottaker som er langt utenfor fagfeltet, eller som er yngre enn elevene, er at elevene da ofte vil forenkle språket og bruke færre faglige begrep (2016, s. 40).

I det norske prosjektet SKRIV var en av erfaringene at elevenes tekster i liten grad var rettet mot mottakere og formål, og at bruksaspektet ved skrivinga dermed var lite vektlagt (Smidt, 2011). Dette samsvarer med utsagn fra intervju og logger med lærerne i Normprosjektet, der flere ga uttrykk for at de ikke var vante til å tenke på mottakerinstansen i skriveoppgavene de lager. Vi finner det derfor interessant å se nærmere på hvordan mottakerinstansen integreres i skriveoppgaver $\mathrm{i}$ et prosjekt der lærere har fått instruks om å vektlegge nettopp et slikt retorisk, kontekstuelt aspekt.

\section{Teoretiske perspektiver}

Det er særlig to perspektiver som er relevante å trekke fram i en studie som denne - og som har vært gienstand for teoretiske og prinsippielle diskusjoner blant skriveforskere. For det første gjelder det spørsmålet om autentisitet i skoleskriving, og for det andre handler det om den tvetydige kommunikasjonssituasjonen skolekonteksten utgjør.

Autentisitet er et tilbakevendende perspektiv i studier av oppgavedesign og tilrettelegging av skrivesituasjoner i skolen. I en oversikt over ulike måter å forstå autentisitetsbegrepet på, skriver Guariento \& Morley (2001) om «real world needs». De viser til at en måte å forstå autentisitet på kan være at oppgaver er autentiske dersom de knyttes til oppgaver man kan få i det virkelige liv. Duke et al. (2006) sin forståelse av begrepet er i tråd med dette, da de mener at autentisk skoleskriving innebærer at tekster blir skrevet i samme sjangre og med samme formål som tekster utenfor skolen. De viser til utfordringen som ligger i å finne «ekte» lesere for elevenes tekster: «By real here, we mean a reader who will read the written text for its communicative purpose and not solely for evaluation, as so often happens to writing done in instructional contexts» (s. 352). Slik vi forstår Duke et al., mener de altså at skoleskriving ikke er autentisk dersom formålet hovedsakelig er å vise læreren hva man har lært.

Enkelte forskere er inne på at det ikke er en dikotomi mellom autentisk skriving og skolsk skriving, men at det er grader av autentisitet fra "classroom» til "real world» (Pinner, 2014)eller fra lav til høy grad av autentisitet (Hung \& Chen, 2007). En mellomvariant som diskuteres av flere er en form for skriveoppdrag der konteksten er det man kan kalle simulert (Kohnen, 2013; Håland, 2013) eller tilnærmet autentisk (Otnes, 2013). I slike skriveoppdrag antydes potensielle lesere, men tekstene skal ikke leses av disse. 


\section{A. H. Kvistad og H. Otnes}

Andre tilnærminger til autentisk skoleskriving handler mer om hvilke temaer og oppdrag elevene får - om de er relevante og aktuelle i elevenes hverdag, og om de engasjerer elevene (Behizadeh, 2014; Kixmiller, 2004). Dette kan blant annet innebære temaer der læreren ikke nødvendigvis sitter med all kunnskap og en fasit på forhånd. Slik blir læreren en reell leser - ikke bare en som skal vurdere teksten. Guariento \& Morley (2001) skriver om «autenticity trough engagement»(s. 350). Innenfor dette perspektivet spiller det liten rolle hvor relevant oppgavene er for det utenomskolske livet, dersom elevene selv ikke opplever dem som relevante. Dette har følger for hvordan skriveoppgaver introduseres: «It may be possible, for example, to "authenticate" a task to learners through careful explanation of its rationale" (s. 351). Innenfor denne måten å tenke på kan oppgaver altså gjøres autentiske gjennom at læreren begrunner dem.

Ikke minst framhever enkelte at autentisitet kan skapes gjennom interaksjon i klasserommet. I stedet for å fokusere på «real world needs», argumenterer blant andre Ivanič (2004) og Smidt (2009) for å utnytte autentisiteten i en læringssituasjon. Smidt mener at den autentiske sosiale konteksten som klasserommet og egne klassekamerater er, gjerne blir undervurdert. Han påpeker at tanker om at elevene bør få autentiske skriveoppgaver kan føre til at de blir satt til å tenke seg $u t$ av den sosiale konteksten de faktisk befinner seg i (s. 315). Vi støtter oss til denne forståelsen og vil i vår studie behandle oppgaver som autentiske hvis tekstene virkelig er ment å skulle leses av den mottakeren som er oppgitt i oppgaveformuleringen. Dette gjelder enten oppgavene er knyttet til situasjoner innenfor eller utenfor skolen (jf. analysedel 2).

Det andre perspektivet vi ønsker å trekke fram er kommunikasjonssituasjonen i skolen. Formål og mottakerinstans blir mer komplekst i skolekonteksten enn ellers, fordi det ofte er snakk om en tvetydig kommunikasjonsituasjon. Dette gjelder særlig i oppgaver der elever blir bedt om å late som om de skriver til mottakere utenfor skolekonteksten - for å øve seg på skrivesituasjoner som er relevante $\mathrm{i}$ «den virkelige verden». Ulike sett med tekstnormer, de innenfor og de utenfor skolen, kan komme på kollisjonskurs - og disse er blant annet blitt beskrevet som ulike «semiosfærer» (Berge, 1996; Karlsson, 1997; Smidt, 1994). Begrep som er brukt for å beskrive noe av det samme er «dobbel bokføring» (Mehlum, 1994, s. 138) og "dobbel sjangerforventning» (Krogh \& Hobel, 2012, s. 138). I forskningslitteraturen vises det blant annet til lærerens doble rolle som veileder og som karaktersetter (Berge, 1996; Smidt, 1992). Dette vil særlig være tydelig på en eksamen og på tekster skrevet på høyere trinn i skolesystemet. Det kan også være snakk om en "splitting» av mottakerinstansen, da skriveoppdraget ber eleven skrive for en gitt mottaker (som ikke er læreren), mens eleven vet at det er læreren som skal lese og kommentere teksten (Mehlum, 1994; Karlsson, 1997). I vår studie, der det er unge elever og der det ikke er snakk om karaktersetting eller eksamen, er det særlig denne splittingen som er relevant. Det blir altså den motsetningen som Krogh og Hobel (2012, s. 140) har omtalt slik: «(...) adressiviteten udfoldes dobbelt, nemlig dels i tekstens henvendelse til en fiktiv læser, dels i henvendelsen til lærer og skole (...)». I denne artikkelen ser vi blant annet på denne doble kommunikasjonssituasjonen (jf. analysedel 3). 
Til slutt må nevnes at denne delstudien er fundert i det samme teoretiske fundamentet som Normprosjektet i sin helhet. Det innebærer et syn på skriving som kontekstavhengig og formålsrettet (Berge et al., 2017; Solheim \& Matre, 2014), og språkets funksjoner i ulike situasjoner står dermed sentralt. Denne forståelsen er i Normprosjektet blant annet nedfelt i et skrivekonstrukt, kalt Skrivehjulet (Berge, 2005; Evensen et al., 2016). Skrivehjulet opererer med seks såkalte skrivehandlinger: samhandle, reflektere, beskrive, utforske, forestille seg og overbevise. I en slik funksjonell sammenheng inngår også formålet med skrivinga - og mottakerinstansen.

\section{Materiale og metode}

Datamaterialet i Normprosjektet er hentet fra 20 prosjektskoler. Elever fra 3., 4., 6. og 7. trinn har skrevet seks tekster per prosjektår, med utgangspunkt i skriveoppgaver som deres lærere har designet på skolene. Blant de føringene forskergruppa ga for lærernes oppgavedesign, var at elevene skulle skrive innenfor hver av de seks skrivehandlingene i løpet av ett prosjektår. Lærerne på skolen ble fulgt opp av representanter fra forskerteamet, og det ble gjennomført jevnlige samtaler og skoleringsøkter. Her ble det funksjonelle synet på skriving vektlagt, og mottakeren for skrivinga som en del av dette. Det ble også brukt tid på å la lærerne dele sine oppgaveutkast med hverandre for å få kritiske kommentarer og råd.

I denne studien har vi valgt å se på skriveoppgaver som er gitt til elever som har vært med i prosjektet $i$ to år. I Normprosjektet kalles disse elevene 300-elever og 600-elever. 300-elevene har blitt fulgt fra 3. til 4. trinn, og 600-elevene fra 6. til 7. trinn. ${ }^{2}$ Til sammen forholder vi oss til i overkant av 460 oppgaveformuleringer. Disse er samlet inn til forskerne via et skjema som alle prosjektlærere skulle fylle ut og sende inn. I tillegg til selve oppgaveformuleringen, kommer også annen informasjon om skrivesituasjonen og oppdraget fram i dette skjemaet (faglig forankring, skriveformål, mottaker m.m.). Disse opplysningene har gitt oss nyttig tilleggsinformasjon i vårt analysearbeid. Når vi skal se på en eventuell utvikling gjennom prosjektperioden, er det viktig å vise til at det har vært noen små justeringer i oppsettet til skjemaet. I første innsamlingsår skulle lærerne blant annet fylle ut en rubrikk som het «Skriveformål (inkl. ev. mottaker/ leser)». I andre innsamlingsår var mottaker skilt ut som en egen rubrikk: "Ev. mottaker/ leser». Dette kan ha påvirket rapporteringen, noe vi skal komme tilbake til.

I arbeidet med å kategorisere oppgaveformuleringene måtte det gjøres noen valg og tolkninger. Dette giør vi rede for i analysene som følger. Vi har først analysert alle oppgavene ut ifra om de hadde en eksplisitt mottaker eller ikke, før vi deretter har konsentrert oss om ulike aspekt ved oppgavene med mottakere.

\footnotetext{
${ }^{2}$ For elevene som gikk i 4. og 7. klasse ved oppstart av første prosjektår (2012), har vi bare data fra arbeid med skriveoppgaver fra dette ene skoleåret. Siden vi er interesserte i å se på en eventuell utvikling i oppgavedesignet, har vi valgt å ikke ta med skriveoppgaver fra disse trinnene.
} 


\section{Analyse og resultater}

I denne analysedelen vil vi ta for oss tre delspørsmål: 1) I hvilken grad inneholder skriveoppgavene informasjon om mottaker? 2) På hvilken måte kan mottakerne klassifiseres som kjente/ukjente og virkelige/fiktive? 3) Hvordan kan man forstå lærerens rolle som mottaker i oppgavematerialet?

\section{1) Mottaker eller ikke mottaker}

Vi har gjort et forsøk på å systematisere oppgavematerialet i kategoriene «med eksplisitt mottaker» og «uten eksplisitt mottaker». Langt over halvparten av oppgavematerialet har en mottaker. Stort sett er disse innbakt i selve oppgaveformuleringa, men det skjer også at mottaker bare står oppført i det skjemaet læreren skulle sende til forskergruppa. Vi antar da at dette er blitt formidlet muntlig til elevene, og disse oppgavene er i våre analyser blitt kategorisert som oppgaver med mottaker. Selv om vi i skoleringa av lærerne oppfordret til å innlemme et tydelig formål og en mottakerinstans, har likevel flere av oppgavene $i k k e$ en eksplisitt mottaker.

Det viste seg at det finnes noen oppgaver som er vanskelige å plassere $\mathrm{i}$ de to kategoriene, fordi de kan tolkes på ulike måter. Vi viser i tabell 1 noen eksempler på

Tabell 1. Oppgaver med og uten eksplisitt mottaker - eller med uklar mottaker.

\begin{tabular}{|c|c|c|c|}
\hline \multirow[t]{4}{*}{$\begin{array}{l}\text { Med } \\
\text { eksplisitt } \\
\text { mottaker }\end{array}$} & $1 a$ & $\begin{array}{l}\text { Skriv en tekst der du reklamerer for Casa skole. Teksten skal kunne brukes } \\
\text { for å overbevise en på din egen alder til å velge Casa skole fremfor andre } \\
\text { skoler. Teksten skal kunne publiseres i lokalavisen }\end{array}$ & 6. trinn \\
\hline & $1 b$ & $\begin{array}{l}\text { Du har laget nøkkelhus på sløyden. De som er i } 3 . \text { klasse i år skal lage det } \\
\text { neste år. Skriv en forklaring til dem som gjør at de klarer å lage sitt eget } \\
\text { nøkkelhus. }\end{array}$ & 4. trinn \\
\hline & $1 c$ & $\begin{array}{l}\text { Skriv et brev til en i familien din (gjerne besteforelder) der du forteller om } \\
\text { en av uteaktivitetsdagene vi har hatt pá skolen. }\end{array}$ & 6. trinn \\
\hline & $1 d$ & Du skal overbevise klassekompisen din om at Gud finnes. & 3. trinn \\
\hline \multirow[t]{2}{*}{$\begin{array}{l}\text { Uten } \\
\text { eksplisitt } \\
\text { mottaker }\end{array}$} & $1 e$ & $\begin{array}{l}\text { Du har lart mye om Norge og India i over noen uker. Bruk kildene du har } \\
\text { foran deg og skriv en utforskende tekst der du skriver om likheter og } \\
\text { forskjeller mellom Norge og India. }\end{array}$ & 4. trinn \\
\hline & $1 f$ & $\begin{array}{l}\text { Sjå for deg at du er med i det første romskipet som landar på Mars. Skriv } \\
\text { om det du ser og opplever. }\end{array}$ & 6. trinn \\
\hline \multirow[t]{3}{*}{$\begin{array}{l}\text { Uklar } \\
\text { mottaker }\end{array}$} & $1 g$ & $\begin{array}{l}\text { Anmeld et selvvalgt musikkalbum. Overbevis en mottaker om hvorfor } \\
\text { albumet er verdt å lytte på, og hvorfor man eventuelt skal kjøpe det. }\end{array}$ & 7. trinn \\
\hline & $1 h$ & Lag ein reklame for ei vare, som du vil at nokon skal kjøpe. & 4. trinn \\
\hline & $1 i$ & $\begin{array}{l}\text { Forestill deg at du er om bord i et fly som styrter. Du overlever. Fortell om } \\
\text { hendelsen. Fortellingen din skal inn i en bok trinnet lager, tittelen er } \\
\text { "Spenningsfortellinger". }\end{array}$ & 7. trinn \\
\hline
\end{tabular}


oppgaver med eksplisitt mottaker (1a-1d), oppgaver uten eksplisitt mottaker (1e-f) og noen tvilstilfeller (1g-1i). Slik får vi både presentert noe av mangfoldet og bredden i materialet, og vist noen utfordringer i kategoriserings- og kvantifiseringsarbeidet.

Oppgavene med uklar mottaker har gitt utfordringer i vår kategorisering, og de kan også ha skapt forvirring hos elevene. I oppgave $1 \mathrm{~g}$ har læreren oppgitt at man skal overbevise «en mottaker». Det er uklart hvem denne mottakeren skal være, men det er trolig ment at det skal være en annen enn læreren. Det går an å argumentere for at mottakeren implisitt er der: elevene kan trolig velge en mottaker selv, eller eventuelt rette teksten mot alle som potensielt kan like det valgte musikkalbumet. Likevel: Det er ikke lagt noen begrensninger for hvem tekstene skal rettes mot. Denne problematikken gjelder også oppgave $1 \mathrm{~h}$. I oppgave $1 \mathrm{i}$ er det riktignok oppført en publiseringkanal (ei bok). Hvem som skal lese denne boka er imidlertid ikke kommunisert i oppgaveformuleringen. Her kan man argumentere for at oppgaven har mulige mottakere som elevene kan se for seg (medelever, lærere, foresatte). Samtidig kan det like godt være tilfelle at elevtekstene heftes sammen før de havner i ei skuff. I SKRIV-prosjektet var ett av funnene at skrivearbeid bare unntaksvis ble fulgt opp i undervisning etter at tekstene var ferdige (Smidt, 2011, s. 19). Eksemplene i tabell 1 viser noen av de valgene vi har tatt $i$ kategoriseringsarbeidet. Vi har videre valgt å framstille antall oppgaver med og uten eksplisitt mottaker i fire sektordiagram (300-elevenes oppgaver 1. og 2. år og 600-elevenes oppgaver 1. og 2. år). Tvilstilfellene er her inkludert i kategorien «uten eksplisitt mottaker». Disse utgjør imidlertid bare en liten del av materialet.

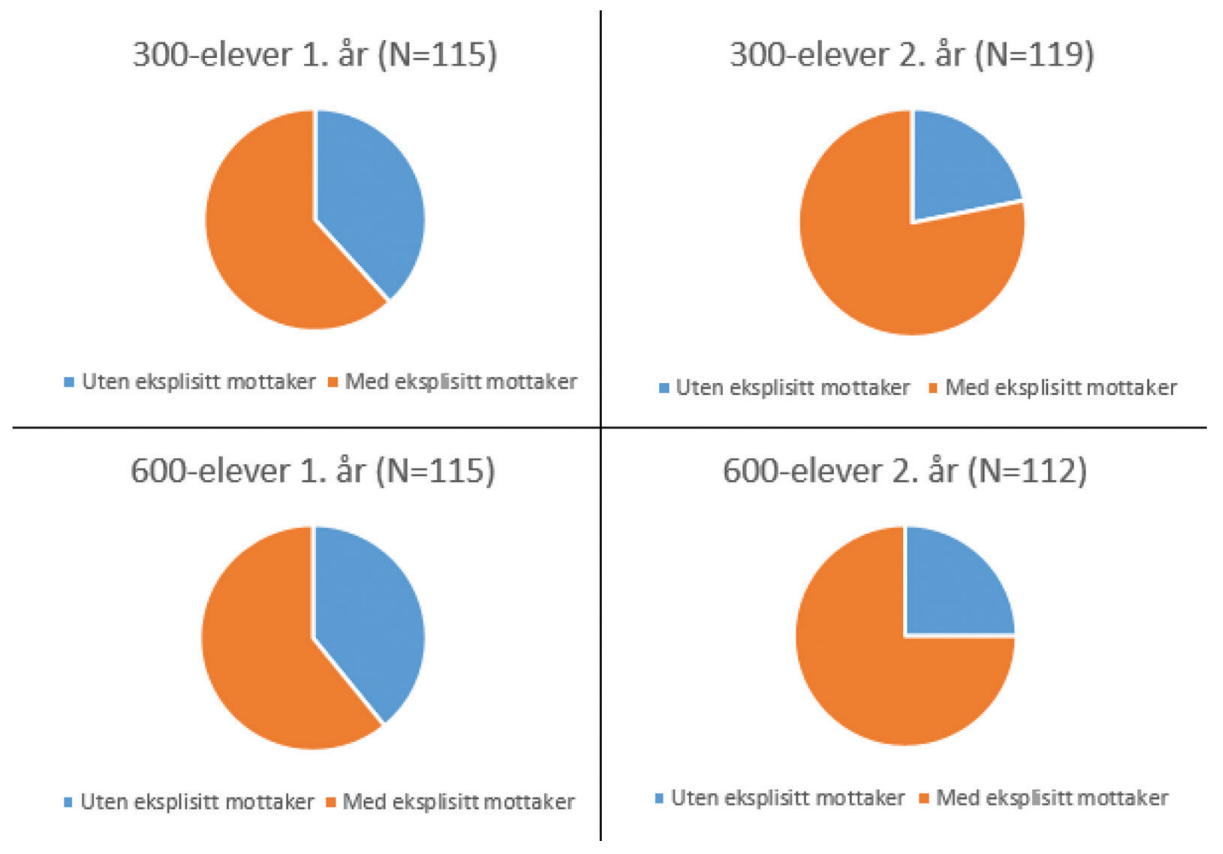

Figur 1. Oppgaver med og uten eksplisitt mottaker. 


\section{A. H. Kvistad og H. Otnes}

Diagrammene viser for det første at det på alle trinn og i begge år er flere oppgaver som har eksplisitt opplysning om mottaker enn det er som ikke har det. Det er også en økning i oppgaver som har opplysning om mottaker fra første til andre prosjektår (3.-4. trinn: fra $62 \%$ til $78 \%$, 6.-7. trinn: fra $61 \%$ til $75 \%$ ). Som tidligere nevnt, kan dette ha blitt påvirket av at mottaker ble lagt til som en egen rubrikk i skjemaet det andre året, og at det dermed var noe lærerne vanskeligere kunne ignorere. Samtidig kan det også skyldes at mottakerperspektivet ble vektlagt i kursing av prosjektlærerne, og at de derfor etterhvert ble mer bevisste på å presisere dette i skriveoppgavene de laget. Det er grunn til å tro at også sistnevnte årsak er av betydning, basert på lærernes egne utsagn i intervju og gjennom loggskriving. En lærer uttrykte for eksempel følgende: «Nyttig å tenke på hvem som skal være mottaker. Det har jeg ikke vært vant til å presisere for elever tidligere».

I materialet er det oftest mottakere i de oppgavene som inviterer til skrivehandlingene overbevise, samhandle og beskrive. Vi viser noen eksempler i tabell 2.

Tabell 2. Mottakere og skrivehandling.

\begin{tabular}{|l|l|l|l|}
\hline $1 \mathrm{j}$ & Fortell om noe du ønsker deg til jul og overtal nissen til å gi det til deg. & Overbevise & 4. trinn \\
\hline $1 \mathrm{k}$ & $\begin{array}{l}\text { Skriv et julebrev til fadderungen din. I brevet forklarer du hvordan du } \\
\text { pleier å feire jul. (...) Flett inn minst 3 spørsmăl der du spør } \\
\text { fadderungen om hans/hennes julefeiring. }\end{array}$ & Samhandle & 6. trinn \\
\hline $1 \mathrm{l}$ & $\begin{array}{l}\text { Skriv en tekst der du forklarer til en person hvordan man kommer seg } \\
\text { til Liastua, og hva man kan gjøre når man er der. Personen du skal } \\
\text { skrive for har aldri vært der før. }\end{array}$ & Beskrive & 3. trinn \\
\hline $1 \mathrm{~m}$ & $\begin{array}{l}\text { Beskriv for en elev som er yngre enn deg forskjellene på partall, } \\
\text { oddetall, primtall og sammensatte tall. Bruk eksempler. }\end{array}$ & Beskrive & 7. trinn \\
\hline $1 \mathrm{n}$ & $\begin{array}{l}\text { Forklar en høytid fra din religion (jul, păske, Id), for en som aldri har } \\
\text { opplevd det før. }\end{array}$ & Beskrive & 4. trinn \\
\hline
\end{tabular}

At det er høy frekvens av mottakere i de to første typene oppgaver, er ikke overraskende, da det på et vis er underforstått at det må være en eksplisitt mottaker for disse handlingene (se $1 \mathrm{j}-1 \mathrm{k}$ ). Her skal man enten overbevise noen eller samhandle med noen. Det er heller ikke overraskende at det er mange beskrive-oppgaver med mottaker. Selv om det å beskrive primært er rettet mot et fenomen (man skal beskrive noe), er det ofte også naturlig å nevne hvem man skal beskrive for (se 11-1n). Det er svært relevant å kjenne til mottakerinstansen når man skal velge detaljeringsnivå og vanskelighetsnivå på beskrivelsen. Mange av beskrive-oppgavene har en type mottakere som er «uvitende» på et eller annet vis. Vanligst er kategorien yngre elev (inkl. fadderbarn), men det er også flere oppgaver der eleven skal skrive til en elev som har vært borte fra skolen og derfor ikke fått med seg et fagstoff. En gjenganger er mottakere som aldri har vært et angitt sted, og derfor må få dette stedet nøye beskrevet.

\section{2) Kjent eller ukjent, virkelig eller fiktiv}

Det fins flere typer mottakere man kan ha for sine skriftlige tekster. Ett skille går mellom kjente og ukjente lesere. Kjente mottakere kan blant annet være familie, venner 
og medelever. Eksempel 2a og 2b i tabellen viser mottakere som eleven kjenner - de er hentet fra nærmiljøet (på skolen eller privat). Oppgave $2 \mathrm{~b}$ er litt misvisende fordi den bruker frasen «kjent person» - som kan ha en annen betydning av ordet «kjent» (= berømt), men den reddes av presiseringen i parentes. Eksempler på ukjente mottakere kan være lesere av en bok eller avis (jf. 2c). Det finnes imidlertid også mellomvarianter med mer eller mindre kjente mottakere. Her er det altså snakk om et kontinuum. En variant av «kjent» kan dessuten være at man ikke kjenner mottakeren personlig, men at man vet hvem det er og dermed har klart for seg hvem man skriver til (se eks. 2d-f).

Tabell 3. Kjente og ukjente mottakere.

\begin{tabular}{|c|c|c|}
\hline $2 a$ & $\begin{array}{l}\text { Du har krasjlandet på en planet. Beskriv hva du ser og opplever. Velg én av de planetene } \\
\text { du har lært om i Namis. Få med noe av det du har lært om denne planeten. Tekstene skal vi } \\
\text { lese opp høyt i gruppa, og medelevene skal gjette hvor du har vært. }\end{array}$ & 4. trinn \\
\hline $2 b$ & $\begin{array}{l}\text { Skriv eit brev til ein kjent person (eit søskenbarn, ein brevven, ei bestemor, ei tante eller } \\
\text { liknande), og fortel om korleis jula di har vert. }\end{array}$ & 7. trinn \\
\hline $2 c$ & $\begin{array}{l}\text { Me har lese og snakke om TV-og dataspel og veit at stadig fleire bruka fritida si på spel. } \\
\text { Lokalavisa vår ynskjer å ha nokre temasider om dette. De ynskjer å få betre innsikt i kva } \\
\text { unge meiner om tv-og dataspel. Du har fätt i oppdrag å undersøkja dette i din klasse. Skriv } \\
\text { ein artikkel der du făr fram (diskuterer) meiningane til klassen. Gjer deg til slutt opp di } \\
\text { personlege meining. }\end{array}$ & 7. trinn \\
\hline $2 d$ & $\begin{array}{l}\text { Din nye kontaktlarer har lyst til å bli bedre kjent med deg. Skriv et brev til ham/henne der } \\
\text { du forteller om deg selv. (...) }\end{array}$ & 7.trinn \\
\hline $2 e$ & $\begin{array}{l}\text { Regjeringen har bestemt at det ikke skal være skolefrukt. Skriv et brev til Erna Solberg og } \\
\text { forklar hvorfor du vil ha skolefrukt. }\end{array}$ & 4. trinn \\
\hline $2 f$ & $\begin{array}{l}\text { Skriv ein tekst der du argumenterer for leksefri skule. Dette skal du sende inn til rektor og } \\
\text { med godkjenning av rektor, muleg vidare til skulekontoret. }\end{array}$ & 7. trinn \\
\hline
\end{tabular}

Nettopp fordi det er snakk om et kontinuum, er det vanskelig å kvantifisere kjente og ukjente mottakere i materialet. Hvor kjent eller ukjent er for eksempel Julenissen, Erna Solberg og helsesøster? Vi har likevel forsøkt å få et overblikk over fordelingen langs dette kontinuumet. Materialet vårt viser at 300-elevene fikk svært få oppgaver som henvendte seg til ukjente mottakere. Som regel skrev de til mennesker i den nære sfæren, for eksempel familie, venner og andre på skolen. Også 600-elevene fikk flest kjente mottakere, men noen flere oppgaver som var retta mot helt eller delvis ukjente mottakere i den offentlige sfære. Dette kunne for eksempel være lesere av magasiner eller brev til offentlige personer og organisasjoner.

Aspektet som gjelder kjente og ukjente mottakere ble tatt opp i skoleringen av lærerne i prosjektet, og det er også med i Normprosjektets såkalte forventningsnormer (Solheim \& Matre, 2014). Der står det at skriveren skal kunne..:

... vende seg på en relevant måte til en eller flere kjente lesere (etter 4. trinn)

... vende seg på en relevant måte til kjente ogleller ukjente lesere (etter 7. trinn)

I disse normene ligger det en forventning om at elevene etter hvert skal kunne skrive til mer ukjente mottakere. Det å skrive til ukjente mottakere betraktes altså som mer 


\section{A. H. Kvistad og H. Otnes}

avansert og innføres som en forventning først etter 7. trinn. Her legges det opp til en progresjon som er i tråd med blant annet Mehlums (1994) ideer om utvikling av mottakerbevissthet fra det nære til det fjerne. Til en viss grad er vårt materiale i pakt med en slik progresjon.

En annen dimensjon når det gjelder mottakere, er fiktive versus virkelige lesere. Denne dimensjonen gjelder spesifikt skoleskriving, fordi man her i stor grad må lage konstruerte skrivesituasjoner. Vårt materiale har eksempler på et bredt repertoar av konstruerte, fiktive mottakere. Vi har forsøksvis systematisert både de fiktive og de virkelige mottakerne $i$ to undergrupper hver (jf. fig. 2).

FIKTIVE MOTTAKERE

$\begin{array}{cc}\begin{array}{c}\text { Fantasi- } \\ \text { figurer }\end{array} & \text { Personer i } \\ & \text { konstruerte } \\ \text { situasjoner }\end{array}$

\section{VIRKELIGE MOTTAKERE}

Tilnærmet

autentiske

mottakere
Autentiske

mottakere

Figur 2. Fiktive og virkelige mottakere.

En type fiktive mottakere er fantasifigurene, det være seg julenissen, en marsboer eller Tuku og Taka i landet Fiktiv (jf. tabell 4, 2h). En annen type er mottakere eleven får i en konstruert skrivesituasjon, på et annet sted og/eller i en annen tid, og der eleven selv må gå i inn i en rolle, for eksempel som et barn i middelalderen eller som en flyktning (jf. 2i). Slike empatioppgaver (Brooks, 2008; Otnes, 2015) er det mange av i materialet. Den fiktive mottakeren er ofte en venn eller et familiemedlem av dette fiktive barnet.

De mottakerne vi har kategorisert som virkelige, er slike som virkelig finnes i samfunnet rundt elevene (i eller utenfor skolen) og som potensielt kunne være mottakere for tekstene de skriver. Det er imidlertid en forskjell mellom de oppgavene der elevene må late som om de skriver til disse personene og oppgaver der de angitte leserne faktisk skal lese teksten. De første tilhører de vil kalle virkelighetsncere eller tilncermet autentiske, og i materialet her har vi mange eksempler på slike - blant annet statsministeren eller FNs generalforsamling (jf. 2j). Det fins også flere eksempler med lokalavisas lesere, der tekstene aldri blir sendt inn til avisa. De andre er det vi vil kalle helt autentiske mottakere. Eksempler er egne foreldre (2k), rektor eller en syk klassekamerat som er hjemme fra skolen. Det kan også være lokalavisas lesere, hvis tekstene faktisk blir sendt inn til avisa. I en del tilfeller kommer det ikke klart fram av oppgaveformuleringen om den nevnte leseren faktisk skal lese teksten. Det kommer heller ikke fram av skjemaet, så her mangler vi kontekstinformasjon. Vi antar at mange av dem er i kategorien tilnærmet autentiske, da det er praktisk vanskelig å gjøre alle disse autentiske. Det er ellers interessant å merke seg at rektor er en mottaker som går igjen i oppgaver på alle trinn - men det er uklart hvor mange tekster som virkelig endte på rektors pult. 
Tabell 4. Eksempler på ulike varianter av fiktive og virkelige mottakere.

\begin{tabular}{|c|c|c|c|c|}
\hline \multirow{2}{*}{$\begin{array}{l}\text { FIKTIVE } \\
\text { MOTTAKERE }\end{array}$} & Fantasifigur & $2 \mathrm{~h}$ & $\begin{array}{l}6 . \\
\text { trinn }\end{array}$ & $\begin{array}{l}\text { Tuku og Taka i landet Fiktiv vet ikke hva divisjon og multiplikasjon er. } \\
\text { Forklar hva multiplikasjon og divisjon er, slik at Tuku og Taka forstår } \\
\text { hvorfor du bruker multiplikasjon og divisjon i ditt liv. }\end{array}$ \\
\hline & $\begin{array}{l}\text { Personer i } \\
\text { konstruerte } \\
\text { situasjoner }\end{array}$ & $2 i$ & $\begin{array}{l}7 . \\
\text { trinn }\end{array}$ & $\begin{array}{l}\text { Tenk deg at du og familien din har flykta frá eit land til Noreg. Skriv eit } \\
\text { brev til besteforeldra dine eller ein ven i landet du kom frå, og fortel } \\
\text { korleis du har det og korleis det er i Noreg. }\end{array}$ \\
\hline \multirow[b]{2}{*}{$\begin{array}{l}\text { VIRKELIGE } \\
\text { MOTTAKERE }\end{array}$} & $\begin{array}{l}\text { Tilnærmet } \\
\text { autentisk } \\
\text { mottaker }\end{array}$ & $2 \mathrm{j}$ & $\begin{array}{l}7 . \\
\text { trinn }\end{array}$ & $\begin{array}{l}\text { Du skal holde en tale til verdens ledere i FN. Du skal prøve å overbevise } \\
\text { lederne til å satse mer på fornybare energikilder. }\end{array}$ \\
\hline & $\begin{array}{l}\text { Autentisk } \\
\text { mottaker }\end{array}$ & $2 k$ & $\begin{array}{l}3 . \\
\text { trinn }\end{array}$ & $\begin{array}{l}\text { Skriv en tekst med overskriften «Fra maggot til flue». Du må bruke det } \\
\text { du har læert for å forklare hva som har skjedd. Teksten skal du først og } \\
\text { fremst legge frem for foreldrene dine. De kontaktlæererne som ikke har } \\
\text { vært med på forberedelsen, skal også lese teksten. }\end{array}$ \\
\hline
\end{tabular}

Det er få helt autentiske oppgaver i materialet vårt - i alle fall få der vi med sikkerhet vet at mottakeren virkelig har fått lese teksten. Ikke overraskende finner vi de fleste autentiske mottakerne i den nære sfæren, da det er enklest å få til naturlige kommunikasjonssituasjoner med kjente lesere som foreldre og venner. I de oppgavene der elevene skal gå inn i rolle som et barn i en helt annen situasjon, skal de også ofte skrive til noen av det fiktive barnets nærmeste. Dette vil da på ett vis være «kjente» mottakere, men for eleven er det jo ikke det - de må dermed forestille seg den nære relasjonen. Her får vi interessante, og kanskje kompliserende, kombinasjoner mellom dimensjonene kjent/ukjent og fiktiv/virkelig.

Vi mener at vårt materiale har vist at en gradering og/eller hierarkisk kategorisering av mottakere er fruktbar. Det viser at det ikke er en klar dikotomi mellom fiktive og virkelige eller mellom kjente og ukjente mottakere. Dessuten får det fram at det å innføre en mottaker i en skriveoppgave, kan virke kompliserende og kunstig i en del situasjoner.

\section{3) Læreren som mottaker}

Studier har vist at læreren er den mest vanlige mottakeren for elevtekster (Applebee \& Langer, 2011). Det ligger i lærerrollen å fungere som en vurderer og veileder for elevenes skriving. I tillegg er læreren en mottaker som elevene har en relasjon til og som de vet er interessert $\mathrm{i}$ å lese tekstene deres. I materialet vårt ser vi imidlertid at læreren kan være mottaker på ulike måter: som reell kommunikasjonspartner (ofte i en ikke-faglig kontekst), som kontrollør/respondør/vurderer eller som den egentlige leseren $\mathrm{i}$ en konstruert situasjon med en fiktiv eller tilnærmet autentisk mottaker («dobbel kommunikasjonssituasjon»).

I kolonne 1 viser vi eksempler på oppgaver som legger opp til en reell kommunikasjon. Elevene vil her, gjennom å skrive til læreren, kunne være med på å påvirke noe i skolemiljøet. Disse oppgavene har et formål som handler om noe mer enn å bli vurdert av læreren; elevene skal snarere kommunisere med læreren. I kolonne 2 ser vi 
Tabell 5. Lærer som mottaker.



\section{Læreren som lærer}

«Vel eit av husdyra som vi har arbeidd med $\mathrm{i}$ denne perioden. Fortel om levemăten til dyret, $»$ (3. trinn)

«Vel deg ein planet i vårt solsystem. Forklar kva som er ulikt mellom denne planeten og jorda vắr. Drøft korleis det ville vere ả bu på denne planeten. » (4. trinn)

\section{Dobbel kommunikasjon}

«Tenk deg at det kjem ein ny elev $\mathrm{i}$ klassen som aldri har høyrt om islam. Du veit mykje om dette emnet. Skriv ein faktatekst der du lærer den nye eleven om islam. $n$ (6. trinn)

«Tenk deg at bestevennen din har med seg boller, kaker og iste hver dag på skolen. I tillegg er han lite aktiv băde i friminutt og pá fritiden. Du ser at han blir slapp, trøtt og sur utover dagen. (...) Bruk det du har lært om kosthold i mat og helse, og fysisk aktivitet i KR $\varnothing$ og overbevis vennen din om hvorfor han mả endre matvanene sine og aktivitetsnivået sitt. (...) Skriv et brev til vennen din. (...). $\%$ (6. trinn)

de typiske «skoleoppgavene», der læreren skal kontrollere elevenes faglige utvikling og skal gi respons og vurdere elevenes arbeid. I vårt materiale har disse oppgavene til felles at læreren ikke står oppført som mottaker i selve oppgaveformuleringen, men kun i skjemaet. ${ }^{3}$ I kolonne 3 er det eksempler på oppgaver som har andre mottakere enn læreren. I disse to eksemplene skal elevene skrive til henholdsvis en ny elev i klassen og en venn. I den første oppgaven er det tydelig at denne personen ikke er en autentisk mottaker. I den andre oppgaven skal man tenke seg at man skriver til sin bestevenn, men denne bestevennen pålegges visse egenskaper. Det er derfor også her tydelig at situasjonen er konstruert, noe som i begge tilfeller forsterkes av de innledende ordene "tenk deg». Her vil elevene forstå at det egentlig er en annen mottaker for tekstene, og at denne mottakeren er læreren (jf. dobbel kommunikasjonssituasjon). I mer autentiske skrivesituasjoner, der elevene faktisk skal skrive til for eksempel familien sin, er elevene også her klare over at læreren trolig kommer til å lese tekstene. Elevene må altså ofte ha flere mottakere i hodet på samme tid når de skriver tekster ${ }^{4}$ (se bl.a. Karlsson, 1997). Dette kompliserer bildet ytterligere.

\footnotetext{
${ }^{3}$ En del oppgaver som har blitt kategorisert som uten eksplisitt mottaker i analysedel 1, kunne trolig ha blitt kategorisert under kolonne 2 her - men oppgaver uten eksplisitt mottaker er ikke inkludert i analysedel 2 .

${ }^{4}$ I Normprosjektets tilfelle kan vi kanskje snakke om en trippel mottaker, siden elevene samtidig visste at de var en del av et forskningsprosjekt. En av lærerne har for eksempel ført opp følgende mottaker i mottakerrubrikken for en av sine oppgaver: «Oss lærere og dere i Normprosjektet».
} 


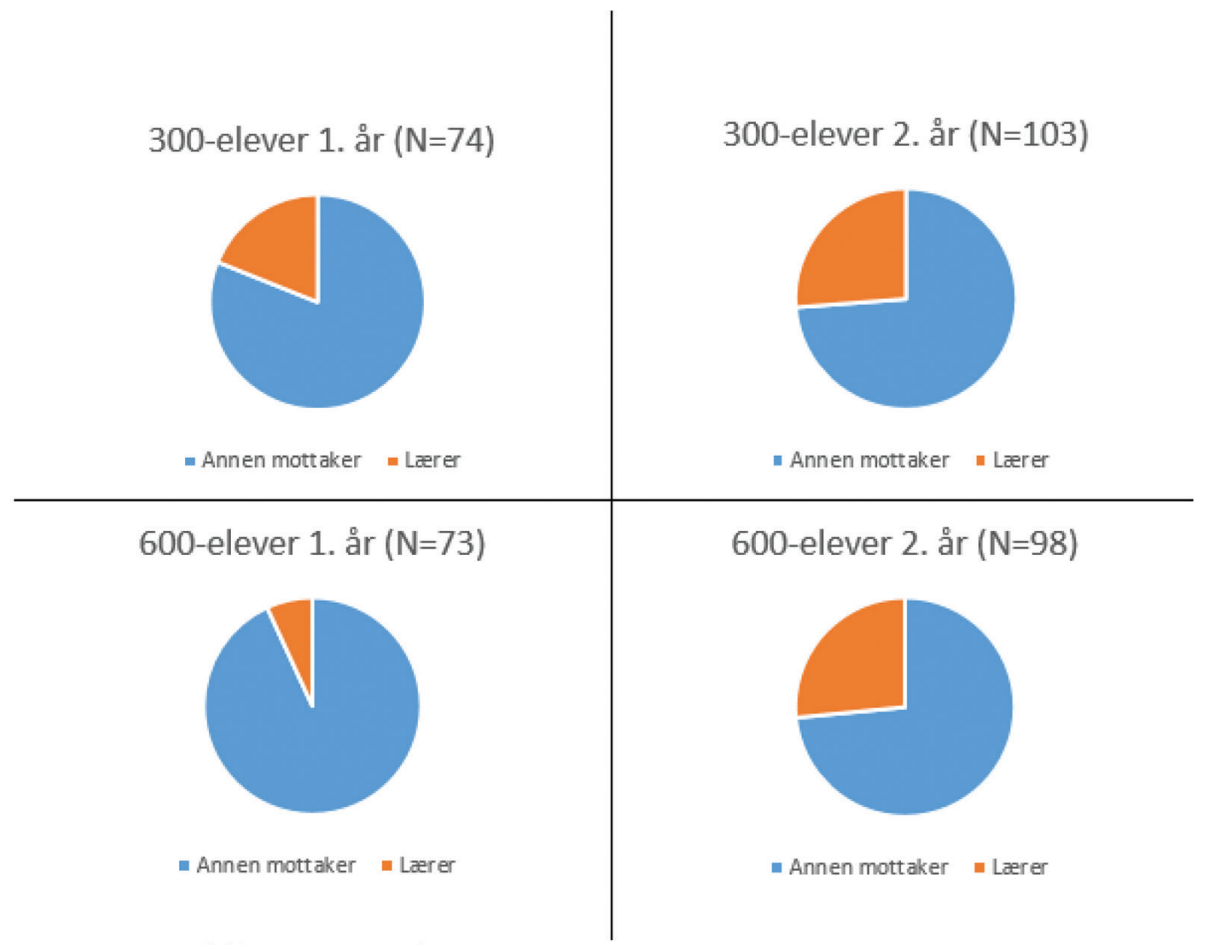

Figur 3. Prosentandel lærer som mottaker.

Vi har ønsket å finne ut om det skjedde noen utvikling i løpet av prosjektperioden når det gjelder om oppgavene har opplysning om lærer som mottaker (kolonne 1 og 2) enten i selve oppgaveformuleringa eller i skjemaet. For å finne ut av det, har vi tatt det totale antallet mottakere, og fordelt dem i kategoriene «Lærer» og "Annen mottaker». ${ }^{5}$

Diagrammene i figur 3 viser at det har skjedd en utvikling fra første til andre prosjektår. Prosentandelen av lærer som mottaker har økt for både 300-elevene (fra 19\% til 26\%) og 600-elevene (fra 7\% til 27\%). Dette kan ha flere årsaker. For det første ble oppgaveskjemaet justert noe fra første til andre prosjektår (jf. metodedelen), noe som kan ha ført til at det ble vanskeligere for lærerne å "unngå» å skrive inn en mottaker her. Det er sannsynlig at dette førte til at de typiske «skoleoppgavene» som før manglet mottaker, fordi det var underforstått at det var læreren som skulle lese tekstene, ble ført opp med en eksplisitt mottaker i det andre prosjektåret (jf. kategori 2: Læreren som lærer). For det andre har flere oppgaver i det andre prosjektåret blitt ført opp med mer enn én eksplisitt mottaker, for eksempel «eleven selv + læreren» eller «lesere av lokalavisa + læreren». Her ser vi muligens spor av en økt bevissthet om

${ }^{5}$ For en del av oppgavene var det ført opp flere mottakere - for eksempel «Foresatte + oss lærere». Alle mottakere er inkludert i oversikten. 


\section{A. H. Kvistad og H. Otnes}

hvem som egentlig er mottaker av tekstene elevene skriver, og kompleksiteten i det å lage skriveoppgaver (jf. "Dobbel kommunikasjon»).

\section{Drøfting av funn}

Materialet for denne studien er hentet fra et prosjekt med bestemte rammer for oppgavedesignet, blant annet med føringer for at oppgavene burde ha en eksplisitt mottaker. Vi kan derfor ikke si at funnene er representative for hvordan skriveoppgaver $\mathrm{i}$ barneskolen ser ut. Vi mener likevel at de 460 oppgavene kan vise mangfoldet, bredden og kreativiteten i hvordan lærere fra 20 skoler lager oppgaver på ulike trinn og i ulike fag. Vi har sett stor variasjon i læreres oppgavedesign og stor oppfinnsomhet når det gjelder mottakeraspektet. Elevene har fått skrive til alt fra romvesener og steinaldermennesker til verdensledere og forfattere.

Ett av funnene i studien er at elevene i prosjektet i stor grad blir satt til å skrive til det vi kan karakterisere som mottakere i den nære sfære. Dette kan for eksempel være medelever, venner og familie. Aller oftest er dette læreren, og vi har vist at dette særlig gjelder i det andre prosjektåret. Kanskje betyr dette at lærerne har fătt mer erfaring med hvor viktig det er at mottakeren er relevant for skrivesituasjonen, og at læreren i mange tilfeller er den mest autentiske mottakeren for elevenes skriving? Poenget er ikke alltid å tenke seg ut av den kommunikative situasjonen man uansett er en del av i klasserommet, slik Smidt (2009) minner oss om.

Et annet funn er at det er få helt autentiske skrivesituasjoner i materialet, om man ser bort fra de der elevene skriver for å vise læreren hva de har ervervet av faglige kunnskaper og ferdigheter. Det viser seg at det av praktiske grunner ikke er mulig alltid å gi elevene autentiske mottakere utenfor skolekonteksten. Noen ganger må man lage simulerte kontekster og mottakere. Innenfor skolekonteksten går medelever - og da gjerne yngre elever - igjen som mottakere. Vi får tro at disse i en del av situasjonene faktisk leste tekstene og slik sett ble autentiske mottakere i en faglig, skolsk kontekst.

Enkelte oppgaver i materialet har en mottaker som ikke nødvendigvis gjør det enklere for elevene å skrive situasjonsrelevant, og enkelte skriveoppdrag kan framstå som unødvendig komplekse og «kunstige». Dette skyldes trolig en kombinasjon av Normprosjektes føringer for hva skriveoppgaver skulle inneholde, og at lærernes oppgavedesign ikke alltid var tilstrekkelig gjennomtenkt. Et eksempel på dette er oppgave $1 \mathrm{~d}$, der elever på 3. trinn skulle skrive en tekst for å overbevise en medelev om at Gud finnes. Denne oppgaven vil mange mene er etisk problematisk, siden læreplanen fastholder at KRLE-faget skal være uten forkynnelse (Utdanningsdirektoratet, 2015). Kanskje er dette en av de oppgavene der det faktisk er helt greit at tekstene forblir i skriveboka til den enkelte, for eksempel som en reflekterende tekst med seg selv som mottaker?

En annen problematikk kan diskuteres i forbindelse med oppgavene der elevene skal skrive til fiktive mottakere som steinaldermennesker og romvesener: Hvordan 
skal man tilpasse teksten sin til disse mottakerne? Hva vet disse fiktive mottakerne om innholdet fra før, og hvilke begrep kan de forstå? Kan man skrive på norsk i hele tatt? Smith \& Swain (2011, s. 13) fra National Writing Project i USA har problematisert nettopp romvesen-eksemplet, og de mener at man ikke bør være «overly clever» når man finner mottakere til elevers skriving. Dette er det lett å være enig i. Formålet med å vektlegge mottakerinstansen i skriveoppgavene må være å lage retoriske situasjoner som lar elevene få øve seg på å tilpasse tekstene sine til ulike mottakere på en hensiktsmessig måte. Hvis man er i overkant kreativ, vikler man seg kanskje inn i problemer og ender opp med å designe skriveoppgaver som nesten er umulige å svare på. Et annet spørsmål det kan være betimelig å diskutere, er hvorvidt elever skal bruke skoletid på å øve seg på å skrive til mottakere som det er åpenbart at de aldri kommer til å skrive til senere i livet. Bør de ikke heller få øve seg på å imøtekomme «real world needs»? På den andre siden har vi forskning som viser at bruk av fiktive mottakere, for eksempel det å skrive brev til Kaptein Sabeltann på første trinn, kan skape engasjement og motivasjon for å skrive (Semundseth \& Hopperstad, 2010, s. 85). Dersom engasjement er den mest avgjørende formen for autentisitet, slik Guariento og Morley (2001) framhever, kan det være god grunn til å være oppfinnsom.

Denne artikkelen starter med et sitat om at læreren alltid må ha en mottaker for skriveoppgaver som elevene skal skrive. Dette er en oppfordring som kan diskuteres. Hva er det som giør at selv i et forskningsprosjekt der lærere blir oppfordret til å spesifisere mottakerinstansen i oppgavene de lager, velger flere å la det være? Vi tror at dette har noe å giøre med at noen ganger er det læreren - og bare han - som er den «naturlige» mottakeren for elevers skriving. Med mindre noe annet presiseres, forstår elevene uansett hvem som skal lese tekstene deres. Et viktig poeng må være at man ikke skal finne på en mottaker kun for å ha med en mottaker, fordi dette kan føre til kunstige skrivesituasjoner - og i noen tilfeller dårligere elevtekster (Ruth, 1982, s. 4).

Når man designer skriveoppgaver, og oppgir mottakere for elevers skriving, er det viktig å være bevisst på hvilke tekster man ønsker at oppgavene skal resultere i. Man bør vite hva målet er, og hvilke tekster man ønsker å få inn. I et eksempel fra materialet skulle elevene skrive til en venn i formatet personlig chat. Her legger både mottakeren og sjangeren opp til et uformelt og internt språk. At man gir oppgaver i skolen som giør at elever holder seg innenfor sin primærdiskurs og den ungdommelige måten å kommunisere på, er problematisert av flere (se f.eks. Friedman \& Pringle, 1989; Håland, 2016; Keech, 1982). Keech (1982) skriver om utfordringene ved å bruke en venn som mottaker for elevers skriving, og påpeker at konsekvensen gjerne er et uformelt og mindre velartikulert språk. Dette kan føre til at tekstene vurderes som dårligere (s. 184). Elever som er gode til å tilpasse tekstene til ulike mottakere, kan altså straffes for dette av den som ofte er den egentlige mottakeren nemlig læreren (jf. den doble kommunikasjonssituasjonen). Er det for eksempel greit at en elev skriver et brev til et romvesen på det som trolig vil være den mest hensiktsmessige måten, nemlig ved hjelp av symboler og tegninger? Kanskje er dette helt fint dersom målet med skriveoppgaven er å reflektere over og utforske språk. Dersom 


\section{A. H. Kvistad og H. Otnes}

målet er å øve seg på å skrive et formelt korrekt brev, er det trolig bedre å velge en annen og mer «jordnær» mottaker.

I denne studien har vi forholdt oss til skriveoppgaver slik de er sendt inn til forskere i skriftlig format. Hvordan lærerne har presentert skriveoppgavene og iscenesatt skrivinga, vet vi lite om. I klasseromskonteksten kan det godt være at oppgavene spontant ble justert, for eksempel etter spørsmål fra elever. Det er ikke bare oppgaveformuleringen som setter premisser for hvordan en elevtekst skal utformes. Det er forskjell på hva en skriveoppgave er (i kraft av oppgaveformuleringen) og hva den blir når oppgaveteksten presenteres av læreren i klasserommet (Bakke, 2019; Bakke \& Skovholt, 2015).

Avslutningsvis vil vi påpeke at mottakerinstansen i skriveoppgaver ikke er avgjørende for et godt oppgavedesign og for en god skriveopplæring - i alle fall ikke alene. Elevene må tilegne seg kjennskap til - og erfaring med - ulike kontekster og ulike språklige og retoriske strategier for å møte disse kontekstene. Det kan være nødvendig å samtale med elevene om hvilken informasjon, hvilke verdier, hvilket språk og hvilke henvendelsesformer som kan være hensiktsmessig i de respektive skrivesituasjonene (jf. f.eks. studier av Flower \& Hayes, 1981). Materialet i vår studie har ikke opplysninger om i hvilken grad elevene fikk hjelp på veien til å skrive på en relevant og god måte til de mottakerne som var oppgitt i oppgavene. Det er imidlertid viktig å ta didaktiske betraktninger som dette inn i planleggingen av skriveundervisning.

\section{Avslutning}

I denne artikkelen har vi vist noen tendenser i skriveoppgavematerialet fra Normprosjektet. Analysene viser blant annet at elever fra 3. til 7. trinn hovedsakelig skriver til mottakere som kan kategoriseres som kjente, og at det er få autentiske mottakere om man ser bort ifra de reelle kommunikasjonssituasjonene mellom lærer og elev og mellom elever. I eventuelle videre studier ville det ha vært interessant å gå til elevtekstene for å se på hvordan ulike mottakere påvirker elevenes skriving.

Arbeidet med oppgaver i Normprosjektet er et arbeid som har hatt betydning. Både forskere og lærere har fått øynene opp for hvor avgjørende oppgavedesign er i skriveundervisninga. Flere lærere ga uttrykk for en slik bevisstgjøring i sine logger til forskerne. En lærer skrev: «Neste gang jeg skal lage skriveoppgaver til elevene kommer jeg til å tenke godt gjennom hvorfor jeg gir de denne oppgaven, og hvem som skal være mottaker». Også utenfor Normprosjektet har vi lagt merke til en økt interesse. I etterkant av prosjektet har flere tatt kontakt med NTNU for å etterspørre kurs i hvordan man lager relevante skriveoppgaver, flere masteroppgaver er skrevet (f.eks. Baastad, 2017; Tjeldflåt, 2018) og artikler om oppgavedesign har kommet inn på pensumlister i lærerutdanninga. Den økte bevisstheten om oppgavenes betydning håper vi fører til at lærere i større grad diskuterer ulike aspekt ved skriveoppgaver både de som har fungert og de som ikke har fungert like godt. Slik kan lærere utvikle seg som oppgavedesignere og lære av hverandres erfaringer. 


\section{Forfatteromtale}

Anne Holten Kvistad er universitetslektor ved Nasjonalt senter for skriveopplæring og skriveforsking, NTNU. Hun har vært med i flere store forskningsprosjekt om skriveundervisning og vurdering av skriving. For tiden er hun koordinator i prosjektet Funksjonell skriving $i$ de første skoleårene. Kvistad har mastergrad i norskdidaktikk, og har også arbeidet ved norskseksjonen på lærerutdanninga ved NTNU.

Hildegunn Otnes er professor i norsk fagdidaktikk ved Institutt for lærerutdanning, NTNU. Hun har skrevet flere artikler innenfor skriveforskningsfeltet. Hun har også vært med på å skrive bøkene Grammatikken $i$ bruk, A invitere elever til skriving og A lare å skrive. Hun har også deltatt i det NFR-finansierte «Normprosjektet», et prosjekt om skriving og vurdering.

\section{Litteratur}

Applebee, A., \& Langer, J. (2011). A snapshot of writing instruction in middle schools and high schools. English fournal (100), 14-27.

Baastad, E. (2017). Moderfag eller morsmålsfag? Norsklcereren 41(1), 131-142.

Bakke, J. O., \& Skovholt, K. (2015). «Å forestille betyr å bruke fantasien til å tenke på noe som ikke fins» Introduksjon av skriveoppgaver på 7. trinn. I H. Otnes (Red.), A invitere elever til skriving. Ulike perspektiver på skriveoppgaver. Bergen: Fagbokforlaget.

Bakke, J. O. (2019). Skriveforløpets dramaturgi:A iscenesette et skriveoppdrag. En kvalitativ studie av skriveundervisning $i$ norsk, samfunnsfag og naturfag på 7. trinn, gjennomført i Normprosjektet (Doktoravhandling). Universitetet i Sørøst-Norge.

Behizadeh, N. (2014). Adolescent perspectives on authentic writing instruction. Fournal of Language and Literacy Education, 10(1), 27-44.

Berge, K. L. (1996). Norsksensorenes tekstnormer og doxa: en kultursemiotisk og sosiotekstologisk analyse (Doktoravhandling). NTNU, Trondheim.

Berge, K. L. (2005). Skriving som grunnleggende ferdighet og nasjonal prøve - ideologi og strategier. I A. Aasen \& S. Nome (Red.), Det nye norskfaget (s. 161-187). Bergen: Fagbokforlaget.

Berge, K. L., Skar, G. B., Matre, S., Solheim, R., Evensen, L., Otnes, H. \& Thygesen, R. (2017). Introducing teachers to new semiotic tools for writing instruction and writing assessment: consequences for students' writing proficiency. Assessment in Education: Principles, Policy E Practice 24(3), 6-25.

Bjørkvold, T. (2013). Autentisk skriving i og utenfor klasserommet: Nysgjerrigpermetoden som eksempel. I D. Skjelbred \& A. Veum (red.), Literacy i lceringskontekster (s. 178-187). Oslo: Cappelen Damm Akademisk.

Bjørkvold, T. (2018). A skape behov for skriving: Literacypraksiser hos elever som forsker (Doktoravhandling). Universitetet i Stavanger, Stavanger.

Black, K. (1989). Audience analysis and persuasive writing at the college level. Research in the Teaching of English, 23, 231-249.

Brooks, S. (2008). Displaying historical empathy: What impact can a writing assignement have? Social Studies Research and Practice, 3(2), 130-146.

Dagsland, S. (2015). Om relasjonen mellom skrivehandlingen «å reflektere», to intendert reflekterende skriveoppgaver og to antatt reflekterende tekster i norsk og matematikk. I H. Otnes (Red.), A invitere elever til skriving. Ulike perspektiver på skriveoppgaver. Bergen: Fagbokforlaget.

Dagsland, S. (2018). Om å jakte på heffalomper: Et metalingvistisk perspektiv på antatt reflekterende og antatt utforskende skriving $i$ norsk og matematikk (Doktoravhandling). NTNU, Trondheim.

Duke, N. K., Purcell-Gates, V., Hall, L. A., \& Tower, C. (2006). Authentic literacy activities for developing comprehension and writing. International Reading Association, 60(4), 344-355.

Evensen, L. S., Berge, K. L., Thygesen, R., Matre, S., \& Solheim, R. (2016). Standards as a tool for teaching and assessing cross-curricular writing. The Curriculum fournal, 27(2), 229-245. 


\section{A. H. Kvistad og H. Otnes}

Flower, L. (1979). Writer-Based Prose: A Cognitive Basis for Problems in Writing Author(s). College English, 41(1), 19-37.

Flower, L., \& Hayes, J. (1981). A Cognitive Process Theory of Writing. College Composition and Communication. 32(4), 365-387.

Freedman, A., \& Pringle, I. (1989). Contexts for developing argument. I R. Andrews (Red.), Narrative and argument (s. 73-84). Milton Keynes: Open University Press.

Gorman, T. P., Purves, A. C., \& Degenhart, R. E. (Red.) (1988). The IEA study of written composition 1: The international writing tasks and scoring scales (s. 3-14). Pergamon Press.

Guariento, W., \& Morley, J. (2001). Text and task authenticity in the EFL classroom. ELT fournal, 55(4), 347-352.

Håland, A. (2013). Bruk av modelltekstar i sakprega skriving på mellomtrinnet. Ei undersøking av korleis modelltekstar set spor $i$ elevtekstar og korleis elevar posisjonerer seg $i$ ulike sakprega skrivesituasjonar (Doktoravhandling). Universitetet i Stavanger, Stavanger.

Håland, A. (2016). Skrivedidaktikk. Korleis støtte elevane si skriving i ulike fag? Oslo: Universitetsforlaget.

Ivanič, R. (2004). Discourses of Writing and Learning to Write. Language and Education, 18(3), $220-245$.

Jørgensen, C. S. (2015). Siden det er du som spør, er vel Jesus svaret! Om skriveoppgaver med relevans for RLEfaget i Normprosjektet. I H. Otnes (Red.), Å invitere elever til skriving. Ulike perspektiver på skriveoppgaver. Bergen: Fagbokforlaget.

Karlsson, A.-M. (1997). Textnormer i och utanför skolan: att skriva insändare på riktigt och på låtsas. Svenskans beskrivning, 22, 172-186.

Keech, C. (1982). Practices in Designing Writing Test Prompts: Analysis and Recommendations. I J. Gray \& L. Ruth (red.), Properties of Writing Tasks: A Study of Alternative Procedures for Holistic Writing Assessment (s. 32-131). Berkeley, CA: University of California.

Kixmiller, L. (2004). Standards without sacrifice: The case for authentic writing. The English fournal, 94(1), 29-33.

Kohnen, A. M. (2013). The authenticity spectrum: The case of a science journalism writing project. The English fournal, 102(5), 28-34.

Krogh, E., \& Hobel, P. (2012). "Årets bedste opgave»: en analyse af en elevtekst i dens kontekst. I S. Matre, D. K. Sjøhelle \& R. Solheim (Red.), Teorier om tekst $i$ møte med skolens lese- og skrivepraksiser. Oslo: Universitetsforlaget.

Kvistad, A., \& Smemo, J. (2015). Den gode skriveoppgave? - En studie av fellestrekk ved vellykkede skriveoppgaver fra Normprosjektet. I H. Otnes (Red.), A invitere elever til skriving. Ulike perspektiver på skriveoppgaver. Bergen: Fagbokforlaget.

Lorentzen, R. T. (2009). Den tidlege skriveutviklinga. I J. Smidt (red.) Norskdidaktikk - ei grunnbok (s. 113-134). Oslo: Universitetsforlaget.

Lykknes, A. (2015). Skriveoppgaver i naturfag fra Normprosjektet. I H. Otnes (Red.), Å invitere elever til skriving. Ulike perspektiver på skriveoppgaver. Bergen: Fagbokforlaget.

Mehlum, A. (1994). Skriveundervisning. Mellom styring og frihet. Oslo: Tano Aschehoug.

NAEP (2011). Writing Framework for the 2011. National Assessment of Educational Progress. National assessment Governing Board, U.S. Department of Education.

Otnes, H. (2013). Fiktive skriveroller og ukjente mottakere. Kontekstualisering i skriveoppgaver. I N. Askeland, E. Maagerø \& B. Aamotsbakken (red.), Lereboka. Studier i ulike lerebokkontekster. Oslo: Akademika forlag.

Otnes, H. (2014). Å designe skriveoppgaver. I A. J. Aasen \& A. Skaftun (Red.), Skriv! Les! 2: Artikler fra den andre nordiske konferansen om skriving, lesing og literacy (s. 237-256). Bergen: Fagbokforlaget.

Otnes, H. (2015). Tildelte skriverroller og posisjoner i skriveoppgaver på mellomtrinnet. I H. Otnes (Red.), A invitere elever til skriving. Ulike perspektiver på skriveoppgaver. Bergen: Fagbokforlaget.

Pinner, R. (2014). The authenticity continuum: Towards a definition incorporating international voices: Why authenticity should be represented as a continuum in the EFL classroom. English today, 30(4), 22-27.

Ruth, L. (1982). Sources of knowledge for designing writing test prompts. Practices in Designing Writing Test Prompts. I J. Gray \& L. Ruth (Red.), Properties of Writing Tasks: A Study of Alternative Procedures for Holistic Writing Assessment (s. 32-131). Berkeley, CA: University of California.

Ruth, L., \& Murphy. R. (1988). Designing writing tasks for the assessment of writing. NJ: Alex Publishing Company.

Scott, F. N. (1903). The teacher and his training. I F. Scott, G. Carpenter \& F. Baker (Red.), The teaching of English in the Elementary and the Secondary School. New York: Longmans, Green, and co.

Semundseth, M., \& Hopperstad, M. (2010). Hiv og hoi: Brevskriving til Kaptein Sabeltann - en meningsfull skrivesituasjon i klasserommet på 1. trinn?. I J. Smidt (red.), Skriving i alle fag - innsyn og utspill (s. 67-87). Trondheim: Tapir Akademisk Forlag. 


\section{Mottakerinstansen i skoleskriving - En studie av skriveoppgaver fra Normprosjektet}

Skar, G., \& Aasen, A. J. (2018). Å måle skriving som grunnleggende ferdighet. Acta Didactica, 12(4). http:// dx.doi.org/10.5617/adno.6280

Smidt, J. (1994). Oppgavesett og skrivesituasjoner - en studie av norske skriveoppgaver i en brytningstid. Skrive-Puff. The DEVEL Project. Trondheim: Senter for samfunnsforskning, Universitetet i Trondheim.

Smidt, J. (2009). Ulike syn på skriving og skriveundervisning. I J. Smidt (Red.), Norskdidaktikk - ei grunnbok (s. 312-316). Oslo: Universitetsforlaget.

Smidt, J. (2011). Ti teser om skriving i alle fag. I J. Smidt, R. Solheim \& A. J. Aasen (Red.), På sporet av god skriveopplaring - ei bok for leerere i alle fag (s. 9-41). Trondheim: Tapir Akademisk Forlag.

Smith, M. A., \& Swain, S. (2011). Wise eyes. Prompting for Meaningful Student Writing. Berkeley, CA: University of California.

Solheim, R., \& Matre, S. (2014). Forventninger om skrivekompetanse. Perspektiver på skriving, skriveopplæring og vurdering i «Normprosjektet». Viden om Laesning (15), 76-89.

Tjeldflåt, S. (2018). Skriving i samfunnsfag. Ein analyse av empati og historiemedvit i oppgåvetekstar og elevtekstar på 7. trinn (Masteroppgave). OsloMet, Oslo.

Vähäpassi, A. (1988). The Domain of School Writing and Development of the Writing Tasks. IT. P. Gorman, A. C. Purves \& R. E. Degenhart (Red.), The IEA study of written composition 1: The international writing tasks and scoring scales (s. 15-40). Pergamon Press.

Utdanningsdirektoratet. (2013). Lareplanverket. Hentet fra https://www.udir.no/laring-og-trivsel/lareplanverket/ Utdanningsdirektoratet. (2015). Lareplan $i$ KRLE (RLE1-02). Hentet fra http://data.udir.no/k106/RLE1-02.pdf 